methods were used, namely: analysis, synthesis, generalization, induction, deduction, analogy. The article focuses on the fact that culturological training of primary school teachers in the countries of Western Europe, which is considered as a complex and multidimensional phenomenon (a set of knowledge, beliefs, relationships, skills, activities of the student, etc.), which, based on the foundation of culture and science, provides: the possibility of selfidentification of students as representatives of national culture, inclusion in the dialogue with other cultures in the domestic educational space, participation in modern European and world civilizations. On the basis of the analysis of scientific sources, the author has formulated a conclusion, which contains the following positions: adoption of the idea of the "European dimension in education" as one of the conceptual provisions of the reform of secondary and higher education systems in European countries has led to the strengthening of the cultural component in the content of the professional training of future teachers in general and primary school in particular; cultural competence is a characteristic of the individual, ready to work in a globalized environment, in which there are a lot of problems in the field of culture and science.

Thus, formation of this phenomenon among primary school teachers in Great Britain, Germany, France is conditioned by the traditions of professional training of teachers, the originality of national systems of secondary and higher education, the trends of reform at the present stage.

Key words Western European countries, European dimension of education, culture, culturological competence, primary school teacher, professional training

удк 378 (410)

Іванова Вікторія

Мукачівський державний університет ORCID ID 0000-0003-3954-9407

DOI 10.24139/2312-5993/2020.02/245-255

\title{
МЕТОДОЛОГІЧНІ ПІДХОДИ В ПІДГОТОВЦІ ВЧИТЕЛЯ ДОШКІЛЬНОЇ ОСВІТИ У ВЕЛИКІЙ БРИТАНІї
}

Досвід системи освіти Великої Британії щодо використання в процесі підготовки вчителя дошкільної освіти пріоритетів у навчанні $і$ вихованні дошкільників цікавий для вивчення з метою його використання для вдосконалення системи дошкільної освіти в Україні. Мета статmі полягає в розгляді методологічних підходів у підготовці вчителя дошкільної освіти у Великій Британії. Практичне значення дослідження базується на результатах дослідження, які полягають у тому, що схарактеризовані методологічні підходи сприяють удосконаленню профресійної підготовки фахівців дошкільної освіти системи неперервної освіти, спонукають до самовдосконалення вчителя-дошкільника до професійного зростання. Подальші наукові розвідки вбачаємо в розкритті особливостей системи дошкільної освіти у Великій Британії та вивченні досвіду підготовки фахівців із предшкільної освіти.

Ключові слова: методологічні підходи, професійна підготовка, підготовка вчителя, дошкільна освіта, країни Західної Європи, Велика Британія, організація дослідницької діяльності, групи наукових підходів.

Постановка проблеми. у будь-якій країні освіта завжди віддзеркалює політичні, соціально-економічні, культурно-історичні та інші суспільні процеси. Тому й головне завдання трансформації соціального 
устрою України в процесі інтеграції у світовий культурний та економічний простір полягає у зміні системи освіти шляхом формування креативної особистості, здатної до професійної мобільності, успішної самореалізації, готової до несподіваних викликів сучасності (Яковишина, 2019), що можливо за допомогою вивчення та впровадження зарубіжного досвіду.

Методологічні підходи фіксують сукупність норм, правил, за якими організовується дослідницька діяльність. Методологічними підходами дослідження нами обрано підходи, орієнтуючись на науковий підхід до здійснення дослідження професійної підготовки вчителів дошкільної освіти у країнах Західної Європи.

Аналіз актуальних досліджень. Стосовно організації сучасної дошкільної освіти у країнах Європейського Союзу, то ця проблема постійно знаходиться в полі зору вітчизняних науковців. Зокрема, проблеми реформування вищої освіти Великої Британії та Європейського регіону $\epsilon$ темою досліджень вітчизняних і зарубіжних компаративістів (Н. Авшенюк, Ф. Богуш, Б. Вульфсон, О. Зима, К. Корсак, В.Кремень, О. Матвієнко, Н. Ничкало, Л. Пуховська, С. Сажник, А. Сбруєва, Т. Степанова та ін.).

Дослідники І. Соколова, С. Сисоєва, С. Цюра виокремили групи наукових підходів, на яких базується дослідження: базові, парадигмальні, інструментальні підходи, які взято нами за основу.

Мета статті: розглянути методологічні підходи в підготовці вчителя дошкільної освіти у Великій Британії.

Методи дослідження. У статті використано методи дослідження: теоретичні (аналіз філософської, педагогічної, психологічної літератури), для обґрунтування вихідних положень дослідження; інтерпретаційноаналітичний метод, на основі якого вивчаються українські й зарубіжні джерела із застосуванням синтезу, аналізу, систематизації та узагальнення; метод порівняльно-історичного аналізу, для виявлення методологічних підходів у підготовці вчителя дошкільної освіти у Великій Британії.

Виклад основного матеріалу. Дослідники І. Соколова, С. Сисоєва, С. Цюра виокремили такі групи наукових підходів: базові, парадигмальні, інструментальні підходи (Цюра, 2013, с. 7-13; Соколова, 2014, с. 25), які взято в нашому дослідженні за основу.

До базових підходів учені відносять: діалектичний, системноцільовий, системно-історичний, синергетичний підходи.

Діалектичний підхід дозволяє вивчити особливості процесуального й теоретичного аспекту проблеми у зв'язку із освітньою політикою, концептуальними підходами та модернізацією професійної підготовки вчителів дошкільної освіти у Великій Британії на основі проведеного аналізу, використовуючи пояснення взаємозв'язків, проведення зіставлення головного й другорядного, загального та особливого; цей підхід допомагає схарактеризувати етапи розвитку процесу підготовки вчителів-дошкільників, 
пояснити причинно-наслідкові зв'язки. Адже він допомагає обгрунтувати методологію компаративного педагогічного дослідження.

На основі аналізу наукових літературних джерел з'ясовано, що діалектичний підхід використовують британські вчені у процесі розгляду проблеми критичного мислення з метою посилення у студентів, майбутніх фахівців дошкільної освіти, здатності приймати аргументовані судження на основі відповідного питання. Розслідування педагогічних проблем за допомогою діалектичного підходу включає в себе визначення й оцінку відповідних аргументів, доказів (за і проти) проблеми. Така оцінка аргументів, як правило, має базуватися на їхній порівняльній оцінці. Учені вважають: для того, щоб знати, наскільки аргумент позитивний, треба його оцінювати в діалектичному контексті (Page, 2016, с. 166-172; Battersby et al., 2015, c. 9-16).

Як видно із зазначеного, для з'ясування педагогічних проблем застосовується діалектичний підхід, який зосереджується на порівняльній оцінці суперечливих аргументів, які наводяться для обґрунтування певної позиції. Силу ж аргументації, доказовості, підтвердження опозиції можна оцінити лише в контексті діалектики, діалектичного підходу.

Значну роль в організації навчально-виховного процесу 3 дошкільниками відіграє синергетичний підхід. Схарактеризуємо його коротко. В. Лутай розглядає синергетичну парадигму як «відносно жорсткий каркас методологічних принципів», що застосовуються зараз у реформуванні освітніх систем, адже синергетична парадигма може вирішити складну проблему про те, що є позитивним у певній культурі, а тому може увійти як унікальний внесок у розвиток сучасного суспільства, а що є негативним, тобто потребує ліквідації (Лутай, 2008, с. 812-813).

В. Прісняков стверджує, що в синергетиці виділяють три ідеї:

- нелінійність - можливість кількох варіантів розвитку системи;

- відкритість - обмін речовиною, енергією, інформацією;

- когерентність - узгодженість, взаємодії елементів, що проявляються в масштабі всієї системи.

Триєдинство створює цілісність, яка перебуває в динамічній рівновазі. Синергетичний підхід дає можливість описати поведінку людини з урахуванням знань і духовної складової (Прісняков, 2008, с. 811-812).

На думку В. Кременя, синергетика нині перетворюється на носіння нової парадигми стилю мислення, вона втілюється в техніку, мистецтво, економіку i, безумовно, повинна проникати в освіту. Поява нової парадигми в науці - це свідчення переходу на якісно новий рівень свідомості, на новий тип розвитку. Цю найбільш фундаментальну проблему науки має вирішити філософія освіти в контексті синергетики (Кремень, 2013, с. 378-379).

Використання синергетичного підходу полягає в організації у 3ВО Великої Британії суворо систематизованих групових аудиторних занять, 
якими керує викладач, та позааудиторних заходів, що забезпечуються вихователем, під час зміни складу студентів, під час демонстрації різного рівня адаптації та соціалізації студентів у процесі підготовки вчителядошкільника. Учені стверджують, що ефективність упровадження синергетичного підходу до процесу адаптації та соціалізації студентів експериментально доведено через розвиток роботи в команді, через організацію активної взаємодії учасників навчально-виховного процесу (A synergistic approach to the promotion of foreign students' socialization and adaptation to the educational environment of higher educational institutions, 2018).

Отже, синергетичний підхід використовується у ЗВО Великої Британії в процесі підготовки сучасного вчителя у процесі активної взаємодії учасників навчально-виховного процесу, розвитку навичок роботи в команді, збагачення навчальної діяльності діалогічними, дослідницькими методами.

Системний підхід до професійної підготовки фахівців дошкільної освіти у Великій Британії $€$ основою більшості сучасних розробок, пов'язаних із освітніми технологіями.

Системний підхід аналізується в працях вітчизняних і зарубіжних учених (Н. Мельник, Ю. Стрункіна, Л. Порохня, О.Суховірський, О. Локшина, В. Загвязинський, П. Оберхюмер та ін.).

Як зазначає В. Нестеренко, системний підхід становить напрям методології наукового пізнання й соціальної практики, в основі якої лежить розгляд взаємодії об'єктів як цілісної структуризованої системи. Системний підхід дозволяє виявити загальні системні властивості та якісні характеристики окремих елементів, що складають систему, розглядати відносно самостійні компоненти не ізольовано, а в їх взаємозв'язку. Специфічною для системного підходу є проблема породження властивостей цілого з властивостей елементів і, навпаки, породження властивостей елементів із характеристик цілого (Нестеренко, 2017, с. 41, 43).

Отже, відповідно до системного підходу до професійної підготовки фахівців дошкільної освіти, система педагогічної освіти Великої Британії характеризується цілісністю, але кожний із його елементів (цілі, зміст, форми, методи) має своє місце, виконує свою функцію. Ці відносно самостійні компоненти розглядаються не ізольовано, а у взаємозв'язку.

Ми зазначаємо, що схарактеризовані наукові підходи (системний, синергетичний, діалектичний), які віднесено до групи базових підходів, дозволяють забезпечити якість виконання дослідницьких завдань, а також обґрунтувати методологію й методику компаративного педагогічного дослідження (Соколова, 2014, с. 25).

До групи «парадигмальні» підходи І. Соколова (Соколова, 2014) i Н. Мельник (Мельник, 2017) відносять: культурологічний, аксіологічний, парадигмальний, акмеологічний. Коротко схарактеризуємо підходи цієї групи. 
С. Сисоєва, аналізуючи взаємозв'язок культури і освіти, розглядає проблему полікультурності переважно в площині культурології, а саме в історико-культурному контексті; у контексті культурологічної підготовки вчителя. Культурологія освіти, стверджує дослідниця, сприяє створенню такого освітнього простору, де найбільш повно взаємодіють різні культури, формується повага до інших культур, поєднання яких створює ту неврівноваженість глобальної культури, яка народжує універсальні цінності, що сприяють її розвиткові та стійкому розвитку зеленої цивілізації (Сисоєва, 2012, с. 131-145).

у здійсненому Н. Мельник дослідженні щодо теоретичних i методичних засад професійної підготовки дошкільних педагогів у країнах Західної Європи культурологічний підхід застосовувався в різних аспектах:

- для аналізу процесу професійної підготовки дошкільних педагогів з погляду культурного історичного досвіду держав Західної Європи, у тому числі й Великої Британії;

- для розкриття єдності загальноєвропейського та індивідуального, національного культурного досвіду організації професійної освіти дошкільних педагогів, що дозволяє виявити спільні тенденції та специфіку національних педагогічних традицій вищої педагогічної освіти;

- для розробки концептуального бачення професійної освіти педагогів, що ґрунтується на культурологічних принципах (методологічних і методичних принципах трактування освіти з позицій культури) та спрямована на формування ціннісно-орієнтованої моделі підготовки вчителів дошкільної освіти.

Застосування культурологічного підходу у процесі підготовки таких педагогів у Великій Британії дозволяє розглянути це педагогічне явище як цілісний динамічний процес, на засадах якого відбувається становлення особистісної культури фахівця. Культурологічний підхід дозволяє вважати цінності й саму систему професійної освіти дошкільних педагогів складовими людської культури (Мельник, 2017, с. 52-53).

Отже, культурологічний підхід змінює не лише зміст, але і якість освіти (певну культуру освіти). Якість при цьому потрібно розглядати не просто як співвіднесення за результатом навчання, але і як її відповідність високому рівню соціальних та особистих потреб.

Акмеологічний підхід спрямований на розвиток майбутнього дошкільного педагога, на вдосконалення професійної діяльності вчителя дошкільної освіти, на його постійне самовдосконалення (Мельник, 2017, с. 57).

Основна сфера акмеологічних досліджень $€$ предметом наукових робіт вітчизняних і зарубіжних учених: І.Зязюна, Т.Левовицького. Н. Ничкало, О. Пєхоти.

Сутнісною характеристикою акмеологічного підходу $є$ прагнення до сприяння досягненням суб'єкта вищих професійних рівнів. Акмеологічний 
підхід орієнтує дослідника на прогноз якісного результату в підготовці педагогічних працівників, на виділення перспективних ідей, на вивчення акмевершин у педагогічній діяльності та проектування продуктивних моделей професійної діяльності. До того ж, акмеологічний підхід активізує дію інших важливих підходів здійснення підготовки вчителя дошкільної освіти, зокрема: аксіологічний підхід, який орієнтує педагога на професійні цінності; системний підхід - до професійної педагогічної діяльності; синергетичний, який передбачає включення синергетичних уявлень у процес підготовки дошкільного педагога (Мельник, 2017, с. 57-58).

Акмеологічний підхід може бути використаний для оптимізації навчальної моделі, організовуючи навчання, спрямоване на підтримку престижу тренінгу. Навчальний процес на основі акмеологічного підходу та педагогічних технологій, що використовуються в цьому процесі, гарантують успіх навчального процесу та сприяють розвитку особистості студента, допомагають виконувати соціальне замовлення (Bakhodir Mamurov, 2019). Аакмеологічний підхід забезпечив розгляд професійної підготовки вчителів дошкільної освіти у Великій Британії та інших країнах Західної Європи (Мельник, 2017, с. 58).

Отже, акмеологічний підхід сприяє підвищенню самовиховання й саморозвитку, тобто особистісному становленню, підвищенню професіоналізму дошкільних педагогів у процесі професійної діяльності.

Значну роль у підготовці вчителя дошкільної освіти відіграє аксіологічний підхід. Взагалі, як стверджують учені, цей підхід має особливе значення в контексті педагогічної сфери (І.Бех, Р. Інглехарт (R. Inglehart), А. Мерабайн (А. M ehrabian), В. Огнев'юк, О. Сухомлинська та ін.). Зарубіжні вчені А. Мерабайн (A. Mehrabian) та H. Епштейн (N. Epstein) аксіологічний підхід пов'язують із тенденцією формування особистості здатності самостійно реагувати на психологічні стани іншої особистості (Mehrabian, 1972, с. 525-543). Таку точку зору підтримує й дослідниця Н. Мельник (Мельник, 2017, с. 54).

На думку О. Соколової (Соколова, 2014, с. 26), аксіологічний підхід сприяє уникнути політичних, світоглядних, наукових та інших помилок у процесі компаративного дослідження. У процесі дослідження проблеми щодо професійної підготовки дошкільних педагогів у країнах Західної Європи аксіологічний підхід, дав змогу аналізувати процес формування професійної компетентності дошкільних педагогів через детермінацію ціннісного ставлення учасників освітнього процесу до змісту й результатів власної діяльності, професійних ролей і позицій (Мельник, 2017, с. 55).

Отже, застосування аксіологічного підходу забезпечує саморозвиток, самоорганізацію навчально-пізнавальної діяльності вчителів дошкільної освіти впродовж усього життя. 
Під час проведенні корпоративних досліджень доцільно використовувати парадигмальний підхід. Парадигманий підхід певний час може забезпечувати моделювання процесу професійної підготовки вчителів дошкільної освіти, але всередині парадигми можуть зароджуватися нові знання, нові напрями, протиріччя, які сприяють руйнуванню фундаменту старої парадигми, у результаті закладаються основи нової парадигми.

Ми погоджуємося з думкою Н. Мельник про те, що парадигмальний підхід до аналізу різних моделей професійної підготовки дошкільних педагогів у країнах Західної Європи дозволяє проектувати різні за характером і цілями системи професійної педагогічної освіти, діагностувати проблеми їх функціонування, прогнозувати результати професійної освіти (Мельник, 2017, с. 57).

Схарактеризовані наукові підходи групи парадигмальних підходів (аксіологічний, акмеологічний, парадигмальний, культурологічний) дозволяють схарактеризувати концепції і теорії, що детермінують процес реформування, модернізації вищої освіти й, зокрема - підготовки вчителя дошкільної освіти (Соколова, 2014, с. 25).

До групи інструментальних підходів віднесені такі: компаративний (порівняльний), герменевтичний, параметричний, інтервальний, наративний, тезаурусуний. Коротко схарактеризуємо їх сутність до аналізу професійної підготовки вчителів дошкільної ланки.

Компаративний (порівняльний) аналіз ґрунтується на порівнянні, на встановленні співвідношення між досліджуваними предметами, явищами, на аналізі подібних і відмінних рис і тенденцій у галузі виховання й освіти, на визначеній перспективі їхнього розвитку, на виявленні в них однакових рис або відмінностей (Великий тлумачний словник сучасної української мови, 2005, с. 880).

Компаративний підхід ґрунтується на методології досліджень у педагогіці, на здійсненні порівняння процесів підготовки фахівців дошкільної освіти різних країн, зокрема він слугував для визначення критеріїв порівняння процесу формування професійної компетентності дошкільних педагогів у країнах Західної Європи, в тому числі й у Великій Британії (Jowell, 1998, с. 168-177).

Для реалізації компаративного підходу вчені застосовують різні методи. Зокрема, дослідниця О. Заболотна - метод контент-аналізу якісно-кількісний метод вивчення документів, який доцільно застосовувати у процесі дослідження професійної підготовки вчителів дошкільної освіти (Заболотна, 2014, с. 19-21); Н. Мельник - метод прогностичний (як засіб формування платформи для виходу корпоративних досліджень на новий рівень), який у процесі проведеного дослідження уможливив визначення перспективних способів, принципів, механізмів та засобів адаптації 
зарубіжного досвіду професійної підготовки дошкільних педагогів країн Західної Європи до умов вітчизняної системи педагогічної освіти (Мельник, 2017, с. 62). Для проведення кооперативних досліджень на сьогодні актуальним $€$ герменевтичний підхід, який дозволяє здійснювати тлумачення й розуміння текстів філософських, соціально-психологічних теорій, а також наукових текстів у вигляді архівних джерел, монографій, періодики тощо різними мовами (Гарага, 2014, с. 162).

Інтервальний підхід базується на результатах процесу, що характеризується стрибкоподібним інтервалом. Особливістю інтервального підходу $є$ те, що його реалізація в дослідженні професійної підготовки вчителя дошкільної освіти забезпечується методом інтервального аналізу, який передбачає вивчення досліджуваного предмета чи явища та формулювання висновків на основі зіставлення різних статистичних даних і даних аналізу на різних рівнях функціонування системи, до якої входить об'єкт (Полуянов, 2012, с. 218).

Параметричний підхід, заснований на характеристиці компонентів ії параметрів. Для процедури порівняння, тобто проведення по елементного аналізу освітніх систем різних країн обраного такі параметри (елементи): концептуальні засади професійної підготовки, освітню політику, цілі, завдання, зміст, методи й форми здійснення професійної підготовки, особливості управління освітніми системами тощо.

Реалізація підходу відбувається на основі методів:

- параметричної оцінки в дослідженні професійної підготовки дошкільних педагогів на основі якісних і кількісних параметрів;

- параметричного порівняння, що являє собою аналіз системи професійної підготовки учителів дошкільної освіти у країнах, що аналізуються (Мельник, 2017, с. 63-64; Соколова, 2014, с. 23-29).

Що стосується наративного підходу, який застосовується для реалізації компаративного дослідження, то зазначаємо, що дослідниця І. Соколова визначає його як спосіб розуміння й відображення історичних феноменів (Соколова, 2014, с. 27) і виокремлює такі його характерні ознаки: ретроспективність (аналіз минулих подій), перспективність (передбачення розвитку в майбутньому), вибірковість (вибирається інформація, яка необхідна для професійної підготовки фахівців дошкільної освіти), комунікативність (здатність до спілкування), які є суттєвими для дослідника, який вивчає проблему підготовки фахівців з дошкільної освіти і порівнює професійну освіту в різних країнах (Соколова, 2014, с. 27; Мельник, 2017, с. 64-65).

Тезаурусний підхід у дослідженні професійної підготовки фахівців дошкільної освіти у Великій Британії відіграє значну роль, адже, як зазначають С. Сисоєва та І. Соколова, він ґрунтується на припущенні, що вся сукупність понять, що використовується компаративістом, моделює 
структуру знання предмета дослідження і що завдяки йому стало можливим виявити відмінні риси у тлумаченні ключових понять дослідження й показати семантичні відношення між лексичними одиницями тексту, у якому лексичні одиниці замінюються дескрипторами (Соколова, 2014, с. 27), які являють собою лексичну одиницю (слово, словосполучення) в інформаційно-пошуковій мові, що служить для опису основного змісту документа (Великий тлумачний словник сучасної української мови, 2005, с. 217).

Висновки та перспективи подальших наукових розвідок. На основі проведеного дослідження можемо зазначити, що кожен зі схарактеризованих нами підходів до здійснення дослідження професійної підготовки фахівців дошкільної освіти у Великій Британії (підходів усіх трьох груп) передбачає вивчення феномену професійної підготовки.

Схарактеризовані наукові підходи сприяють удосконаленню професійної підготовки фахівців дошкільної освіти системи неперервної освіти, спонукають до самовдосконалення вчителя-дошкільника до професійного зростання.

Ми вважаємо, що досвід системи освіти Великої Британії щодо використання в процесі підготовки вчителя дошкільної освіти пріоритетів у навчанні й вихованні дошкільнят є цікавим для вивчення з метою його використання для розв'язання цієї проблеми в Україні.

Перспективи подальших наукових досліджень із означеної проблеми полягатимуть у розкритті особливостей системи дошкільної освіти у Великій Британії та вивченні досвіду підготовки фахівців із передшкільної освіти.

\section{ЛІТЕРАТУРА}

Цюра, С. Б. (2013). Особливості методології порівняльних педагогічних досліджень. Порівняльно-педагогічні студії, 2/3, 7-13 (Tsiura, S. B. (2013). Features of the methodology of comparative pedagogical research. Studies in comparative education, 2/3, 7-13).

Соколова, І. (2014). Наукові підходи до проведення компаративних досліджень в освіті. Освітологія = Oświatologia, 3, 23-29 (Sokolova, I. (2014). Scientific approaches to conducting comparative studies in education. Osvitologiya =0światologia, 3, 23-29).

Page, D. (2016). Understanding performance management in schools: a dialectical approach.International Journal of Educational Management, 30 (2), 166-176.

Battersby, M., Bailin, S. \& van Laar, J. A. (2015). Fallacy Identification in a Dialectical Approach to Teaching Critical Thinking. Inquiry: Critical Thinking Across the Disciplines, 30 (1), 9-16.

Лутай, В. С. (2008). Синергетичний підхід в освіті. В В. Г. Кремень (Ред.) Енциклопедія освіти, (сc. 812-813). К.: Юрінком Iнтер (Lutai, V. S. (2008). Synergistic approach in education. In V. H. Kremen (Ed.), Encyclopedia of Education, (pp. 812-813). K.: Jurinkom Inter).

Прісняков, В. Ф. (2008). Синергетика. Енциклопедія освіти. В В. Г. Кремень (Ред.) Енциклопедія освіти, (сс. 811-812). К.: Юрінком Інтер ( Prisniakov V.F. (2008) Synergetics. In V. H. Kremen (Ed.), Encyclopedia of Education, (pp. 811-812). K.: Jurinkom Inter). 
Кремень, В.Г. (2013). Синергетична модель розвитку освіти як відповідь на виклики сьогодення. Освітологія: хрестоматія. К.: ВП «Едельвейс» (Kremen, V. Н. (2013). A synergistic model of educational development in response to the challenges of today. Educatology. Kyiv: Edelweiss).

A synergistic approach to the promotion of foreign students' socialization and adaptation to the educational environment of higher educational institutions Retrieved from: http://en.sciforedu.ru/article/3384.

Нестеренко, С. А. (2017). Теоретико-методологічні підходи щодо визначення сутності «стратегічний потенціал» В економічній літературі. Вісник ХНАУ. Серія: Економічні науки, 1, 290-297 (Nesterenko, S. A. (2017). Theoretical and methodological approaches to determining the essence of "strategic potential" in economic literature. KhNAU Bulletin. Series: Economic Sciences, 1, 290-297).

Сисоєва, С. О. (2012). Культурологічні концепти освітології в контексті розвитку полікультурного суспільства. Освіта у полікультурних суспільствах. Варшава. (Sysoieva, S. 0. (2012). Cultural concepts of education in the context of a multicultural society development. Education in Multicultural Societies. Warsaw).

Мельник, Н. І. (2017). Теоретичні і методичні засади професійної підготовки дошкільних педагогів у країнах західної Європи (дис. ... д-ра пед. наук: 13.00.04). Умань (M elnyk, N. I. (2017). Theoretical and methodological foundations of professional training of preschool teachers in the countries of Western Europe (DSc thesis). Uman).

Bakhodir Mamurov. Scientific basis of the acmeological approach to the process of training and education. Retrieved from: file:///C:/Users/\%D0\%A2\%D0\%B0\%D0\%BD\%D1\%8F/ Downloads/348-Article\%20Text-659-1-10-20190403.pdf.

Mehrabian, A., Epstein, N. (1972). A measure of emotional empathy. Journal of Personality, Vol. 40, Issue 4, 525-543.

Великий тлумачний словник сучасної української мови (2005). Київ; Ірпінь: Перун (Great explanatory dictionary (2005). Kyiv; Irpin: Perun).

Jowell, R. (1998). How Comparative is Comparative Research? The American Behavioral Scientist, Vol. 42, № 2, 168-177.

Заболотна, О. А. (2014). Застосування контент-аналізу d порівняльно-педагогічних дослідженнях. Педагогічна компаративістика - 2014: якісний вимір освіти зарубіжжя та український контекст : матеріали наук.-практ. семінару, 5 черв. 2014 р., (сс. 19-21). Київ (Zabolotna, O. A. (2014). Application of content analysis in comparative-pedagogical studies. Pedagogical Comparative Studies 2014: A qualitative dimension of education abroad and the Ukrainian context: materials of scientific-practical. seminar, Jun 5 2014, (pp. 19-21). Kyiv).

Гарага, В. (2014). Концептуальні основи педагогічної герменевтики. Молодь і ринок, 4, 59-162 (Garaga, V. (2014). Conceptual foundations of pedagogical hermeneutics. Youth and the market, 4, 59-162).

Полуянов, В.П. (2012). Вивчення природи і соціокультурної реальності із застосуванням інтервальної методології. Вісн. Харків. нац. пед. ун-ту ім. Г. С. Сковороди. Серія: Філософрія, 38, 216-224 (Poluianov, V. P. (2012). Study of nature and sociocultural reality using interval methodology. Visn. Kharkiv. nat. ped. university named after G.S. Skovoroda. Series: Philosophy, 38, 216-224).

Яковишина, Т. (2019). Модель формування креативної компетентності майбутнього вчителя початкової школи. Педагогічні науки: теорія, історія, інноваційні технології, 2 (86), 129-139 (Yakovyshyna, T. (2019). Model of formation of creative competence of future elementary school teacher. Pedagogical sciences: theory, history, innovative technologies, 2 (86), 129-139). 


\section{PEЗЮME}

Иванова Виктория. Методологические подходы в подготовке учителя дошкольного образования в Великобритании.

Опыт системы образования Великобритании по использованию в процессе подготовки учителя дошкольного образования приоритетов в обучении и воспитании дошкольников интересный для изучения с целью его использования для совершенствования системы дошкольного образования в Украине. Цель статьи заключается в рассмотрении методологических подходов в подготовке учителя дошкольного образования в Великобритании. Практическое значение исследования базируется на результатах исследования и заключаются в том, что охарактеризованы методологические подходы способствуют совершенствованию профрессиональной подготовки специалистов дошкольного образования системы непрерывного образования, побуждают $к$ самосовершенствованию учителядошкольника к профессиональному росту. Дальнейшие научные исследования видим в раскрытии особенностей системы дошкольного образования в Великобритании и изучении опыта подготовки специалистов по предшкольному образованию.

Ключевые слова: методологические подходы, профессиональная подготовка, подготовка учителя, дошкольное образование, страны Западной Европы, Великобритания, организация исследовательской деятельности, группы научных подходов.

\section{SUMMARY}

Ivanova Victoria. Methodological approaches to the preschool teacher training in Great Britain.

The experience of the UK education system on the use of preschool teacher preferences in preschool education and training is interesting to study with a view to using it to improve preschool education in Ukraine.

The purpose of the article is to consider methodological approaches in pre-service teacher education in the United Kingdom.

The research is based on the scientific approaches proposed by scientists (I. Sokolova, S. Sysoieva, S. Tsiur): basic, paradigmatic, instrumental approaches, which are taken as a basis in our research. The basic approaches include: dialectical, systems-targeted, systems-historical, synergetic approaches that allow to ensure the quality of the research tasks, as well as to substantiate the methodology of comparative pedagogical research. To paradigmatic approaches we refer: cultural, axiological, paradigmatic, acmeological, which allow to characterize the concepts and theories that determine the process of reforming, modernizing higher education, and in particular - training of preschool teachers. The group of instrumental approaches includes the following: comparative, hermeneutic, parametric, interval, narrative, thesaurus, which are essential for a researcher who studies the problem of training specialists in preschool education and compares vocational education in different countries.

The practical significance of the study is based on the results of the study, which are characterized by the fact that methodological approaches contribute to the improvement of vocational training of preschool education specialists in the system of continuous education, encourage self-improvement of the preschool teacher to professional growth.

Further scientific exploration is seen in the discovery of the features of the preschool education system in the UK and in training of preschool professionals.

Key words methodological approaches, vocational training, teacher training, preschool education, Western European countries, United Kingdom, organization of research activities, groups of scientific approaches. 